\title{
THE IEC AND THE 2014 ELECTIONS A Mark of Institutional Maturity?
}

\author{
Mcebisi Ndletyana
}

\begin{abstract}
South Africa's election management body, The Electoral Commission of South Africa (IEC), faced an unprecedented situation in the run-up to the country's fifth elections. Its chairperson, Pansy Tlakula, was found to have behaved in a manner unbefitting an electoral commissioner. Her misconduct raised concerns about whether or not the IEC would manage the elections impartially. These concerns, together with the prescribed censure for conduct unbecoming of a commissioner, led to a clamour for her removal. The proximity of the elections, however, militated against the resolution of the saga, leading to Tlakula staying on to oversee the elections. This article looks at whether the imbroglio had an impact on the reputation of the IEC. To make this determination, the article draws on survey findings about the IEC's administration of the elections. Part of the spotlight falls on how the responsible institutions, particularly Parliament and the courts, handled the problem. The article employs an institutionalist theoretical framework to explain its conclusions.
\end{abstract}

\section{INTRODUCTION}

Since South Africa's inaugural democratic elections, in April 1994, the management of the country's elections has been largely seamless. The novelty of the first elections and the inadequate preparations, occasioned by the haste with which the election was organised, all combined to give the new South Africa a tumultuous electoral debut. Since 1994, however, there have been massive improvements in election management. The improvements derived largely from the establishment of a permanent, fully-staffed electoral management body, the Electoral Commission of South Africa (hereafter referred to as the IEC), ${ }^{1}$ sufficient time allowed for pre-poll preparations and the creation of the requisite infrastructure and facilities to run elections.

1 The commission's documents and staff continue to refer to the organisation as the IEC, which is the abbreviation that applied to its predecessor, the Independent Electoral Commission. 
The period leading up to the May 2014 election, however, bucked what had become a post-apartheid trend. During that time the IEC was mired in a controversy that threatened to explode into public protests. The dispute, which involved the chairperson of the commission, Pansy Tlakula, was sparked by her relationship with a businessman, Thaba Mufamadi, a member of Parliament (MP) representing the governing African National Congress (ANC) and chairperson of Parliament's finance portfolio committee.

The matter was referred to the Public Protector, Thuli Madonsela, who, in her report, suggested that Parliament should censure Tlakula, a measure that might result in her removal from office. Some opposition parties actively demanded her removal, citing concerns that, because she had demonstrated bias in a business transaction, she might behave similarly by using her influence over the commission to the advantage of the ANC.

The article focuses on this saga and examines two related issues: the handling of the complaint by the responsible public institutions and its general impact on the public perception and credibility of the IEC. The article tracks the parliamentary process that was initiated to probe and recommend a remedy to the complaint, to its referral to the Electoral Court and to the result. The intention is to discern what the handling of this challenging episode says about South Africa's public institutions and public culture. In doing so, the article shines a spotlight on the specific lessons learnt from the saga and on their impact.

The article also probes whether or not the imbroglio impaired the credibility of the commission. The evaluation is based on recent survey findings, which are compared to previous findings to discern whether there is any demonstrable difference in public perceptions of the IEC and its management of elections. The survey findings are explained using an institutionalist theoretical framework, to account for the commission's current standing in public opinion and, most importantly, for how it fared in the management of the May 2014 elections.

The author relies largely on primary data drawn from official documents gathered from the various public institutions, including the courts and Parliament, which were involved in resolving this saga, as well as from an interview conducted with one of the key opposition party leaders. Secondary literature is used to provide further context and clarity to the analysis and conclusions drawn from the empirical data.

The article is structured in four parts. The first outlines the scandal that engulfed the IEC, the second focuses attention on the concerns of the opposition parties, especially as they relate to the indifferent manner in which the ANCdominated Parliament addressed the matter. In the third part, the article examines the survey findings on public perceptions of the IEC. The fourth and last part explains the survey findings, with a particular focus on how we should understand the IEC as an institution. 


\section{ANATOMY OF THE COMPLAINT AND INVESTIGATIVE OUTCOMES}

The complaint against Tlakula involved a lease contract worth R320-million, signed in June 2010 with a property company, Abland, for the IEC's new headquarters, following the expiry of its lease at 260 Walker Street, Sunnyside, Pretoria. The commission moved into the new premises on 13 September 2010 and the building was renamed Election House. It is located within the Riverside Office Park at 1303 Heuwel Avenue, Centurion, Pretoria (Office of the Public Protector 2013).

A report of possible impropriety in the issuing of the lease contract first surfaced publicly in April 2012 in a Sunday newspaper, City Press, in an article titled, 'IEC's offices partly owned by the boss's business partner' (City Press, 28 April 2012). The allegation itself had been brought to the attention of the Public Protector, Thuli Madonsela, more than six months earlier, on 15 October 2011 by the president of the United Democratic Movement (UDM) and member of Parliament (MP), Bantu Holomisa, who had received the information from a whistleblower within the IEC.

The allegation was that Tlakula had influenced the tendering process in order to benefit Abland. What connected Tlakula to Abland was her business relationship with Thaba Mufamadi, her business partner in another company, Lehotsa Investment. Mufamadi has a shareholding in Abland through another company, Manaka Property Investment. Of particular concern in relation to Tlakula was that Mufamadi was a senior MP representing the governing party, the ANC.

Because of her position as chairperson of the commission, Tlakula's association with an MP of the governing party raised concerns that she might use her position to benefit his party. In a memorandum addressed to the commissioners and forwarded to the Office of the Public Protector on 27 July 2012, a group calling itself ‘Concerned Electoral Commission Employees' expressed concerns:

That the trust and respect that South Africans, political parties and the rest of the world have put on us the Electoral Commission is now at stake. One of the questions that may be asked is, if a high profile member of a political party especially ruling party pulls strings of the Chairperson and the face of an organization like the Electoral Commission what is that the party will get from that organization? The much talked-about 'treating all parties equally, impartially and independence issues' of what the Electoral Commission has been known for all the years of its existence are undoubtedly compromised. 
That the authenticity and integrity of the work that we do, is likely to start raising questions such as why political party ' $\mathrm{A}$ ' is winning or losing or that IEC has rigged the election and so on.

We have never before been associated with such questions, but the new developments will undoubtedly make us counted amongst other Election Management Bodies that no longer care about such questions and doubts.

Another fear or concern is that our leaders: Councillors, MPLS, and MPs walk with pride wherever they go as the whole world have never doubted their election which is the phenomenon we see in other countries, particularly in Africa.

cited in OPP report 2013, pp 27-8

Subsequent investigations by the Office of the Public Protector (OPP) and later an audit firm, PricewaterhouseCoopers $(\mathrm{PwC})$, validated the allegation of impropriety on Tlakula's part. For her part, and after more than two years of investigation, Madonsela found that Tlakula was biased both in the manner in which she handled the process and in how she drew up the specifications for the bids, with the clear intention of benefiting Abland.

Firstly, Tlakula had rescinded the original decision of the commission ${ }^{2}$ to award the contract to Menlyn Corporate Park. In doing so, and acting in her capacity as CEO, Tlakula declared that the original process had been carried out improperly. She correctly pointed out that the tender had never been opened up to competitive bidding, but that Menlyn had been invited to make a presentation, based on which it was then appointed. In cancelling the initial award Tlakula was supposedly rectifying a flawed process. She then committed to steering the new tendering process correctly. What followed, however, as the OPP subsequently uncovered, was an even more irregular process.

The initial sign of irregularity was that the application process was unusually short. The bid was advertised for fewer than the required minimum of 14 days stipulated in the IEC's procurement policy. Interested parties had no more than 11 days (7 working days) within which to submit their proposals. Moreover, the advertisement was only placed in newspapers, not in the Government Tender Bulletin. Regulations require that such advertisements be placed in the Bulletin.

2 The commissioners at the time were Brigalia Bam, Thoko Mpumlwana, Fannie van der Werwe, Herbert Vilakazi and Judge Herbert Msimang. 
Abland received preferential treatment from the moment it submitted its application. One of many examples of favours extended to Abland uncovered by PwC's forensic investigation was the fact that the method of Abland's submission did not follow the proper channels. Instead of being physically submitted and posted in the tender box, the submission was emailed. This means it might not even have arrived on time. Two other incidents cited in the forensic report, which was concluded on 14 December 2013, but only made public on 18 March 2014, deserve specific mention.

Firstly, Stephen Langtry, a manager in the CEOs Office, misrepresented the contents of a bid from Kwela City, both in terms of the size of the office space that would be allocated to the IEC and the rental fee. Their bid stated that their premises had a total of 27000 square metres and that 9000 of that would be allocated to the IEC as per its requirements. In evaluating the bids, however, Langtry did not make that distinction. Rather, he wrote that Kwela had the entire 27000 square metres available for the IEC, which made the premises too big for the commission's requirements. Langtry also entered Kwela's rates incorrectly as R116.28 per square metre, instead of the real R102 per square metre with generator or R105 per square metre without generator.

Secondly, the commission wanted 1 April 2010 to be the occupation date, and companies such as Kwela City that stated a date beyond that were disqualified. Yet, once it had been shortlisted and called to make a presentation, Abland changed the occupation date from 1 April to 1 August 2010 and the change did not disadvantage it. Its competitor, Menlyn Park, lost out even though it gave as occupation date 1 April 2010, as required (PwC Forensic Investigation, 14 December 2014).

One reason why it was possible for Tlakula to prejudice others in favour of Abland was that she was in charge of the entire tender process. Whereas the three phases of the process - bid specification, evaluation and adjudication - were often differentiated, in this particular case they were all centralised in the CEO's office. Evaluation of bids and short-listing, for instance, was undertaken by Langtry, a manager in the CEO's office. The presence at the evaluation meeting of other senior managers, such as the two deputy CEOs and the communication manager, made no difference. They endorsed Langtry's evaluating sheet, with all its inaccuracies. This suggests that they had not even read the original submissions, but took Langtry, evaluations at face value.

The Public Protector, therefore, concluded that a conflict of interests led to Tlakula committing irregularities that amounted to misconduct. According to the Electoral Act such an offence constitutes sufficient grounds for removal from the commission. Madonsela did not prescribe the nature of the punishment, instead she suggested that the Minister of Finance institute a forensic investigation to probe the matter further, that the speaker of the National Assembly advise the 
president on a course of action and, most importantly, and according to the founding legislation of the IEC, the her report be referred to the Electoral Court for a decision. Only the Electoral Court can preside over a dispute involving a commissioner and recommend to the president what the punishment should be.

\section{PARLIAMENTARY HEARINGS}

The events that followed the Public Protector's report proved quite instructive and set a precedent. For not throughout the 20-year history of South Africa's democracy had a commissioner faced possible removal from office due to misconduct. Because of the novelty, and also due to self-interest, numerous and contrasting interpretations were proffered about what should happen.

Following the Public Protector's recommendations about remedial actions, the speaker, Max Sisulu, constituted an ad hoc committee whose purpose was to study the report, deliberate over its recommendations and advise Parliament what to do. The committee, made up of $12 \mathrm{MPs}$, seven from the ANC and five from opposition parties, sat for just over a month, from 19 September to 24 October 2013. An ANC MP, Lewellyn Landers, was elected chairperson (Parliament: Ad Hoc Committee September 2013).

Once the ad hoc committee had been constituted and its mandate explained, it got down to the gist of its assignment. But MPs were unclear about the application of the IEC law to the Tlakula case, or the powers of Parliament vis-à-vis the OPP's recommendations. DA MP James Selfe, for instance, sought clarity from legal advisors on whether the Electoral Court had jurisdiction to deal with the matter. The uncertainty stemmed from the fact that Tlakula had committed the misdemeanor in her capacity as CEO, not as a commissioner, over whom the Electoral Court is explicitly empowered to preside in the instance of irregular conduct. At issue here, in other words, was whether or not the court could look into a case of impropriety committed by a commissioner whilst employed as CEO. This would turn out to be Tlakula's defence as well, as discussed further below (Parliament Ad Hoc Committee October 2013).

Another MP, Koos van der Merwe of the IFP, wanted to know whether the committee could overturn the recommendations of the OPP in a manner 'similar to [that of] an Appeal Court'. The question was apt, as it related to the nature of the advice sought from the committee. To some degree, this also spoke to the powers of Parliament in relation to the OPP's findings. Was its advice to be limited purely to procedure, or could it extend to overturning the substance of the findings. There was no precedent to guide the committee.

Equally worth noting is the way the committee handled the matter. It not only relied on the OPP's report and on parliamentary legal advice, it also called 
on the implicated party, Pansy Tlakula; the Public Protector, Thuli Madonsela, and on some of those who had been commissioners during Tlakula's tenure as CEO, namely Brigalia Bam and Thoko Mpumlwana, to appear before it. Tlakula was called to give her version of what had happened and to defend herself against the OPP's findings, Madonsela to provide clarity on her findings, and the former commissioners to explain parts of the report the MPs found unclear. This procedure was critical as it set a precedent for the way Parliament could handle future OPP reports (Parliament: Ad Hoc Committee October 2013).

Tlakula's testimony deserves special mention because it provides a useful background to the conclusions of the committee as well as to the subsequent findings by the Electoral Court. It revolved primarily around her powers as CEO, a definition of conflict of interests and the powers of the Electoral Court vis-à-vis disputes relating to commissioners (Tlakula, October 2013).

On the issue of the powers of the CEO Tlakula argued that, as the accounting officer, she was empowered to take decisions if she considered it necessary to expedite the work of the commission. In this particular case she had believed that the commission had insufficient time to follow the usual process stipulated for tenders because it had to find new premises in time to start preparing for the 2011 local elections. That was the reason, as noted above, that she had decided, among other things, to shorten the period allowed for submission of bids.

Tlakula denied any conflict of interests, asserting that her business relationship with Mufamadi related to Lehotsa Investment (Pty) Limited, in which she is a co-shareholder and director. That relationship did not extend to Manaka, the company that holds a share in Abland. Because she was not part of Manaka, Tlakula insisted that there was no conflict of interests on her part.

Tlakula's contested the finding on the conflict of interests on the basis that she he had not benefited financially as a result of Abland getting the lease contract. That, she maintained, was another reason why she had not thought it necessary to disclose the business relationship to her colleagues when they were processing applications for the lease.

As for the powers of the Electoral Court, Tlakula raised the same matter that had perplexed the MPs, maintaining that it was clear that the Electoral Court had no jurisdiction over the actions of the commission's CEO. Although she was now a commissioner, the allegation related to her tenure as $\mathrm{CEO}$ and therefore the court had no right to hear the matter - the only body that had the right to hear the matter was the previous commission, whose term had expired (Tlakula, October 2013).

Despite the fact that she maintained her innocence, she did not want the case to be referred to the Electoral Court but insisted that the matter be settled on a technicality. 
The legal opinion sought by the ad hoc committee concurred with Tlakula. Essentially, it advised that there was nothing that either Parliament or the court could do. The lawyers believed it was inappropriate of the OPP to instruct Parliament what do: '... the Public Protector is not authorized to dictate to the Speaker as to how to conduct parliamentary affairs as this would infringe upon the principle of separation of powers and the rule of law.' Moreover:

... the National Assembly is not legally empowered to refer the Public Protector's Report to other forum, including the Electoral Court, as this would impede on the independence, dignity and effectiveness of the Office of the Public Protector. Such conduct would offend the doctrine of legality and might expose the National Assembly to successful judicial challenges.

Ad Hoc Committee, October 2013, p 2

Even if the OPP had such referral powers, 'the Electoral Court lacks jurisdiction to investigate the current Chairperson'.

The committee ruled that Parliament could not follow the OPP's recommendations for remedial action and that the electoral commission and Treasury should 'complete the actions in which they are currently engaged in pursuance of the "Remedial Action" recommended by the Public Protector in this Report in so far as is legally permissible' (Ad Hoc Committee, October 2013, p 3). Parliament thus absolved itself of responsibility for the matter, discouraged any thoughts of referring it to the court and provided no guidance about what Treasury and the IEC could do once the forensic investigation was concluded. The matter seemed poised for stalemate, if not to disappear completely.

Parliament's decision added to the suspicion of connivance between the ANC and Tlakula. The Public Protector's findings that Tlakula had unfairly awarded a lease contract to a senior ANC MP was sufficient to create doubt about the IEC's credibility. This is clear in the abovementioned memoranda written by IEC staff. Parliament's decision not to act smacked of an attempt to protect Tlakula. It appeared even more so when Treasury sat on the findings of PwC's forensic investigation. PwC submitted the report on 14 December 2013. But Treasury released it to the public much later - on 14 March 2014. Even then, Bantu Holomisa maintains that opposition parties forced Treasury into releasing the report. Without their constant pressure, Holomisa believes, Treasury would not have done so. ${ }^{3}$

To Holomisa, Treasury's behaviour only served to heighten suspicions of collusion between the governing party and the chairperson of the IEC. Accordingly,

3 Interview with the author, 25 August 2014. 
together with other opposition parties, ${ }^{4}$ Holomisa called for Tlakula's resignation. If she continued in her position, they argued, the impartiality of the IEC would be in question. The ANC and the official opposition, the DA, opposed the call, saying it would disrupt preparations for the election, which was scheduled for 7 May 2014.

The other four commissioners disagreed, however, insisting that the commission would operate perfectly well without its chairperson. They accepted the remedial action recommended by the Public Protector and insisted that they be implemented. One of the commissioners, Raenette Taljaard, while lauding the parliamentary probe into the OPP's report, expressed dismayed that the process had got that far. She maintained that the appointment of commissioners rested 'on the tacit assumption that IEC Commissioners be people of honour and integrity who would resign if found wanting' (Mail \& Guardian, 11 October 2013). IEC employees were a lot more direct than Taljaard in their call for Tlakula's resignation. Citing concerns that the credibility of the IEC might be dented by Tlakula's continued stay at the commission, they threatened to strike if she did not resign (Mail \& Guardian, 11 April 2014).

The contrasting stances of the various political parties are worth noting. At one level, the fact that there were varying interpretations of the law was not unexpected. Neither Parliament nor the courts had ever had to take a decision about the possible removal of an electoral commissioner. The reasoning advanced by the majority party and the official opposition, however, suggested a reluctance to even have the court rule on the matter. Yet there was no harm in following that course of action. If, indeed, the Electoral Court was not empowered to preside over the case, it would simply have said so. But, they didn't even want the process to get to that point.

Concerns that court proceedings involving the chairperson of the commission might disrupt elections did not hold either - elections are run by IEC employees, dispersed throughout the country. The other four commissioners disputed the possibility of disruptions and were keen to have the saga brought to an end.

The source of the reluctance to proceed appeared to lie elsewhere and, in the case of the DA, it is not clear what that source was. With respect to the ANC, however, it is probably that the reluctance was influenced by the party's attitude to Thuli Madonsela herself. Her report was issued at the height of a vitriolic campaign launched by the party-in-government to deligitimise the Office of the Public Protector, accusing Madonsela of malicious attempts to discredit Jacob Zuma's administration. Members of the ANC even hurled insults at her person, ridiculing her looks (see Cape Times, 26 August 2013).

4 The other parties were: the Economic Freedom Fighters, the African Christian Democratic Party, Agang SA and the Congress of the People. 
The cause of the vitriol was her findings that President Zuma had benefited personally from state expenditure on his rural homestead, Nkandla. Madonsela had found that, in improving security at the president's private home, the state had spent close to R250-million, some of it on items that were not related to the safety of the president. These included a swimming pool, landscaping, a chicken run, a cattle kraal and a reception area within the house. Madonsela recommended that the president reimburse what was spent on items that were intended for his personal comfort and that of his family (OPP March 2014).

Parliament's handling of the OPP's report, therefore, did not lift the cloud of suspicion that was hovering over the IEC. This was not ideal for an election management body. If the outcome of an election is to be credible, the standing of the IEC must be above reproach.

\section{FREE AND FAIR ELECTIONS: PREREQUISITES}

Independence is critical to the integrity of an election management body and bestows credibility on the election results. Maphunye (2010, p 61) compares the role of an election management body to that of a referee 'who protects both players and teams against bias, fraud, or any illegal activities likely to compromise the game'. For a post-conflict society such as democratic South Africa, the integrity of an electoral commission is particularly important. Because of the country's history of conflict and the relative newness of the democratic dispensation, trust has not been easy to build. Co-habitation is fairly new, following centuries of racial segregation and animosity. And political parties have not been working together for long enough to consolidate trust in one another. ${ }^{5}$

Recognising the absence of trust in South African institutions, the drafters of the Constitution were particularly emphatic about ensuring the independence of the election management body. For instance, elections are generally administered in one of three ways: independently, by the state, or a combination of the two. The latter entails, among other things, the appointment of independent commissioners to assume a supervisory role, while the actual administration is left to the state. Post-apartheid South Africa opted for an independently administered electoral process. Both commissioners and the bureaucracy of the commission are independent of the state.

The independence of the commission is assured in four ways: constitutional guarantees, the profile of the commissioners, the selection process and financial control.

5 The following paragraphs in this section are drawn from a book chapter titled: 'The Making of the Independent Electoral Commission, 1993-1997' in Ndletyana (Forthcoming: 2015). 
The fact that the Constitution asserts the independence of the commission obliges government, or any other party, to refrain from interfering with its operation. In instances where the institution suspects interference, it has recourse to the courts, which will rule in accordance with the law.

Commissioners, who may not be prominent in political organisations, are selected by an independent panel chaired by the chief justice and made up of the chairpersons of the six independent state institutions created by Chapter 9 of the Constitution to support constitutional democracy. Commissioners can only be removed from office on the recommendation of the Electoral Court because of misconduct, incompetence or incapacity. Parliament, in other words can neither appoint nor dismiss commissioners and the commission has complete control over its budget.

These provisions, designed to ensure that election results are accepted by all parties, secure the independence of the commission and its freedom from any political influence or association. But the standing of the body itself is just as critical in bestowing credibility upon the results.

Therefore, the concern that greeted the revelation of Tlakula's close relationship with a senior ANC MP and the fact that she consciously violated the law to award him a contract lease unfairly was not unjustified. If she could do him a favour which helped him to benefit financially, what else might she do?

\section{JUDICIAL INTERVENTION}

Following Parliament's decision that nothing could be done about Pansy Tlakula the UDM approached the Electoral Court. On 14 November 2013 Holomisa wrote 'seeking guidance' from the Court on:

19.1 whether Adv Tlakula and other senior IEC officials should be let off the hook and they be allowed to avoid taking responsibility for their transgressions.

19.2 whether Adv Tlakula is fit to be the Chairperson of the Commission.

19.3 which would be the correct body to preside over the matter

The court replied on 19 November, declining the request to offer guidance. But the refusal was not based on the merits of the case, it was based on a technicality. The acting president and chairperson of the Electoral Court explained that:

[t]he powers, duties and functions of the Electoral Court are stipulated in section 20 of the Electoral Commission Act 51 of 1996. Giving advice and guidance to potential litigants is not one of them. The Electoral 
Court must operate within the four corners of the relevant statutory provision. To do otherwise could create an untenable situation and would compromise the adjudication powers vesting in the court to hear and determine matters brought before it. It has no powers outside those set out in the Act.

It is therefore suggested that you seek legal advice and guidance from Attorneys Advocates or other suitably qualified legal advisers.

Holomisa did not follow the advice immediately, but waited for PwC to complete its forensic investigation, which it did in December 2013. As stated above, the report, which was handed to Treasury, was only made available to the public in April 2014, at which point, about two weeks before the election, the UDM approached the Electoral Court again.

In her response to the UDM's application Tlakula changed her previous argument that the court could not preside over an allegation of impropriety committed whilst she was a CEO, but could only do so if she had committed the alleged wrongdoing in her capacity as a commissioner. Now, writing to the Court, Tlakula noted:

We submit that the Electoral Court is therefore empowered to make a recommendation to the National Assembly concerning the removal from office of a Commissioner, but only after the Electoral Court has investigated an allegation of misconduct, incapacity or incompetence against the Commissioner concerned.

Correspondence from Mkhabele Huntley Adekeye Inc, April 2014

Having admitted that the court could indeed hear the matter, Tlakula now merely objected to the UDM's argument that the court should hear the case urgently. If it were heard immediately, she argued, it would disrupt preparations for the May 2014 elections.

No good reason exists why the Chairperson of the Electoral Commission should be deflected from her duty to chair the Commission during the forthcoming national and provincial elections. In particular, the removal of the Chairperson from office at this juncture would place the functioning of the Commission in jeopardy. Decisions of the Commission, where not reached by consensus, have to be taken by a majority of Commissioners. Presently, the Commission comprises 5 members. An even number of Commissioners could result in a 
deadlock, which is not envisaged or regulated by the Electoral Act or the Constitution ....

The role of the Chairperson, as one of a Commission of 5 members, is particularly crucial both during the elections and thereafter. In this regard we point out that, within 48 hours of the voting day, any interested party may lodge with the Commission an objection, in terms of Section 55 of the Electoral Act, 73 of 1998, that is material to the determination of the final results of the election. A decision on any such objection is a decision of the Commission. With only 4 Commissioners, the possibility of deadlock is real.

The court agreed that, given the proximity of the elections, there was insufficient time to conduct a proper investigation. It deferred the hearing to 4 June. On 18 June Judge Lotter Wepener handed down a 73-page judgement, stating, inter alia:

In my view, the respondent compromised the independence and integrity of the Commission to such an extent that her actions complained of constitute misconduct within the meaning of the Electoral Commission Act. It is conduct which renders her unsuitable for the office of a commissioner and destructive of the very values of the Commission.

This court recommends that a committee of the National Assembly adopts the facts, views and conclusions of the court and that it finds that the respondent has committed misconduct warranting her removal from office.

United Democratic Movement [UDM] and Others $v$ Tlakula and Another, p 72

In other words, the judge set a precedent, ruling that commissioners might be punished for misconduct committed before they were appointed as commissioners. According to the judge, the IEC Act insists on absolute moral probity and thus seeks to prohibit a commissioner from behaving in a manner that places 'in jeopardy his or her perceived independence or in any other manner harms the credibility, impartiality, independence or integrity of the Commission (UDM $v$ Tlakula, p 16). He further elaborated:

The conduct of the respondent, which may prove to be misconduct on her part, whether during the time after her appointment as 
a commissioner or before, would constitute conduct which may harm the Commission ... What is important is the possible effect of the respondent's conduct on the independence, credibility and integrity of the Commission. It would, in our view, be artificial to say that misconduct which came to light after the appointment of a commissioner, which may have impacted on her very appointment - had it been known, and which could have disqualified her from office, cannot be investigated by this court.

UDM v Tlakula, p 16

Despite the scathing judgement, Tlakula refused to resign, choosing instead to appeal to the Constitutional Court to overturn the verdict of the Electoral Court. The Constitutional Court declined to hear the appeal, dismissing the application with costs and stating in its ruling: 'The Constitutional Court has considered this application for leave to appeal. It has concluded that the application should be dismissed, as it bears no prospects of success' (Constitutional Court, 13 August 2014).

\section{PUBLIC PERCEPTIONS OF THE IEC: SURVEY FINDINGS}

Surveys conducted by the Human Sciences Research Council (HSRC) since 1998 reveal that public trust in the IEC is fairly high. It was highest in 2009, with $72 \%$ of the population expressing trust, while the lowest rating was registered in 2000 at $49 \%$. More people expressed trust in election years, especially in the case of national and provincial elections. From a low of 54\% in the 1999 (national) election year, the percentage of people who trust the IEC rose to $69 \%$ in 2004 and $72 \%$ in 2009 (Roberts 2014).

At the time of writing the results for 2014 were not yet out, but a survey done on election day showed that a massive number of voters approved of the IEC's work. About $97 \%$ felt that the election procedures were free and fair and $97 \%$ were satisfied that their ballot was secret. Asked to rate IEC officials on different aspects of their services to gauge their efficiency substantive numbers of voters (between $73 \%$ and $85 \%$ ) rated them positively on such aspects as professionalism, honesty, friendliness, helpfulness and knowledge of elections (Roberts 2014b). Based on these findings it is likely that the general survey for the year 2014 will prove that the institution continues to enjoy high levels of trust amongst a large majority of the population.

The fact that the results of the election-day survey suggest that the Tlakula saga did not impair the public image of the IEC raises the question of why this should be so. The answer is twofold. One relates the conduct of the IEC on the 
day, the other to the IEC as an institution. As noted above, IEC staff performed in a manner that was perceived to be impartial. The second reason is that the way in which the IEC staff handled the scandal also had an affect on how people perceive the commission.

The fact that the information about possible wrongdoing came from a member of the staff and that the staff pursued the matter and called for action showed their determination not only to unearth wrongdoing but to have the culprit punished. More importantly, the members of the IEC defined Tlakula's misconduct as an anomaly within the commission, from which they wished to distance the IEC.

The whistleblowers were particularly worried about the stain Tlakula's transgression could leave on the commission, a sign that they have not only internalised the values of the commission, but also champion them.

The conduct of the IEC staff epitomises an organisation that has matured as an institution, which is more enduring than a mere organisation.

While institutions put into operation the laws upon which society is founded, compliance with institutional behaviour does not only stem from the laws, it draws on societal norms and values that define acceptable social behaviour. People within institutions then internalise this ethos (North 1991; Ostrom 1986).

Once a particular behaviour is repeated frequently it becomes habitual and requires less supervision or enforcement. People become self-regulating and deviant behaviour, because it is atypical of the institution, attracts disapproval from others. The conduct of the IEC staff, therefore, should be understood from the perspective of ingrained institutional behaviour.

Equally worth noting is that institutions reinforce each other. One institution cannot become vibrant if other similarly important institutions are weak (Hodgson 2003). The resolution of the Tlakula controversy had as much to do with the OPP, the media, opposition parties and the courts, as it had with the IEC staff. It took an opposition party to alert the OPP, which then investigated the complaint without any favour or prejudice. The media brought the saga to the attention of the public and followed the story closely, to its conclusion. The courts took up the matter and brought it to finality. Each of these institutions played a critical role in ensuring that the IEC has been able to rid itself of any elements that might compromise its work and reputation. It's quite possible that if any of these institutions was compromised the Tlakula saga would not have been resolved in a manner that reaffirms the integrity of the commission.

\section{CONCLUSION}

This article probed the way in which the recommendations of the Public Protector in relation to the chairperson of the IEC were handled by the responsible bodies. 
Attention was paid to the various institutions that are authorised to handle a complaint against an IEC commissioner. The article also examined what the resolution of the IEC saga implied about the IEC as an institution and in terms of its public standing.

The maturation of the IEC as an institution is shown by the fact that staff have internalised its values and take pride in being part of the institution. They are therefore vocal in their defence of the commission and what it stands for. The fact that the Tlakula saga did not affect public perceptions of the IEC confirms that the commission has performed commendably over the years and has engrained itself, in public consciousness as a credible body. For this reason, an isolated act of impropriety failed to undermine its public standing. The behaviour of the staff also affirmed public confidence in the integrity of the commission.

The way the Tlakula saga was resolved is testimony to the vibrancy of other democracy supporting institutions. It took more than the Public Protector to bring the complaint to a conclusion. Opposition parties were instrumental not only in bringing the complaint to light, but also in seeing that it was resolved in the face of the reluctance of the governing party. The media kept the public informed and interested, which alerted the OPP to the importance of the matter. The courts not only provided a resolution, they set a precedent.

As a result, commissioners are not only held accountable for their behaviour while they are commissioners, their prior conduct is taken into consideration. If it is discovered after a person has been appointed to the commission that he or she has behaved in a manner unbecoming of a commissioner, he or she may be removed. The Electoral Court has raised the moral standards to which commissioners are held. This will go a long way towards ensuring that the commission is staffed with individuals of unquestionable moral standing and will thus enhance the integrity of the IEC.

\section{REFERENCES}

Cape Times. 2013. 'Madonsela must do her job: Mantashe', 26 August. Available at: www.iol.co.za

City Press. 2013. 'IEC's offices partly owned by the boss's business partner', 28 April.

Available at: www.citypress.co.za

Hodgson, G. 2003. 'The Hidden Persuaders: Institutions and Individuals in

Economic History'. Cambridge Journal of Economic History 27.

Holomisa, B. 2013. Correspondence with the Electoral Court, 14 November.

Mthiyane. 2013. Correspondence with Bantu Holomisa, 19 November.

Mail \& Guardian. 2013. 'IEC must act without fear or favour', 11 October. Available

at: www.mg.co.za 
Mail \& Guardian. 2014. 'Staffers threaten strike if IEC head is not removed - reports', 11 April. Available at: www.mg.co.za

Maphunye, K. 2010. 'Evaluating Election Management in South Africa's 2009

Elections'. Journal of African Elections 9(2).

Mkhabele Huntley Adekeye Inc. 2014. United Democratic Movement ('UDM') And Others/Advocate Pansy Tlakula and the Electoral Commission', 22 April.

Ndletyana, M. Forthcoming 2015. 'The Making of the Independent Electoral Commission, 1993-1997'. In M Ndletyana (ed). Institutionalising Democracy: The Story of the Electoral Commission of South Africa. Pretoria: AISA Press.

North, D. 1991. 'Institutions'. The Journal of Economic Perspectives 5(1).

Office of the Public Protector (OPP). 2013. 'Inappropriate Moves'. Report 13 of 2013/14, 13 August.

OPP. 2013. 'Secure in Comfort'. Report No 25 of 2013/2014, 19 March. Available at: www.publicprotector.org

OPP. 2013 'Inappropriate moves'. Report No 13 of 2012 / 2013, 26 August. Available at: www.publicprotector.org

Ostrom, E. 1986. 'An Agenda for the Study of Institutions'. Public Choice 48.

Parliament: Ad Hoc Committee. 2013a. Public Protector's Report 13 of 2013/14, Minutes of Meeting, 19 September.

Parliament: Ad Hoc Committee. 2013b. Public Protector's Report 13 of 2013/14, Minutes of Meeting, 24 October.

Parliament: Ad Hoc Committee. 2013c. Public Protector's Report 13 of 2013/14, Minutes of Meeting, 31 October.

PricewaterhouseCoopers. 2013. 'Forensic Investigation: Electoral Commission:

Riverside Office Park', 14 December. Available at: www.Treasury.gov.za

Roberts, B. 2014. 2014 National and Provincial Elections Satisfaction Survey. Pretoria: Human Sciences Research Council.

Roberts, B, M Kivilu \& Y D David. 2010. South Africa Social Attitude Survey. Pretoria: Human Sciences Research Council.

Taljaard, R. 2014. 'IEC must act without fear or favour'. Available at: www.mg.co.za Tlakula, P. 2013. 'Representations by the Adv P Tlakula: Chairperson of the Electoral Commisison to the Ad Hoc Committee of the National Assembly of the Republic of South Africa on the Public Protector's Report No. 13 of 2013/2014', 9 October.

Tlakula, P. 2014. 'Affidavit'. Submitted to the Electoral Court, 25 April.

United Democratic Movement and Others v Tlakula and Another. 2014. 'Applicants' Concise Heads of Argument', submitted to the Electoral Court, 25 April.

United Democratic Movement and Others v Tlakula and Another (EC 05/14) [2014] ZAEC 5, 18 June 2014. 